\title{
KONTEMPLASI TUJUAN PENDIDIKAN AKUNTANSI: INTERPRETASI MAKNA BERBAGAI PERSPEKTIF
}

\author{
Yohan Bakhtiar \\ Program Studi Akuntansi - Politeknik Kediri \\ yohan_bakhtiar@yahoo.co.id
}

\begin{abstract}
This study is a contemplation about accounting education objective from various perspective in accounting education research. Qualitative approach with interpretive paradigm are used in this study. The result of this contemplation is various perspective to formulate accounting education objective appropriate with national education objective, UUD 1945, and lesson goal in KKNI. There is only a little difference on redactional aspect however the substance is similar.
\end{abstract}

Keyword: Accounting Education, Objective, Perspective

\section{PENDAHULUAN}

Penelitian-penelitian dalam ranah ilmu akuntansi di Indonesia pada umumnya masih didominasi oleh bidang akuntansi keuangan. Namun, dengan semakin berkembangnya paradigma dalam ilmu akuntansi maka semakin beragam pula lah bidangbidang dalam penelitian ilmu akuntansi. Tidak hanya dalam bidang akuntansi keuangan, terdapat pula akuntansi lingkungan, akuntansi syariah, akuntansi keperilakuan dan juga pendidikan akuntansi. Sejatinya, pendidikan merupakan salah satu aspek penting dalam membangun suatu peradaban ilmu pengetahuan. Filosofi pendidikan yang bernafaskan kritis para pemikirnya menjadi tonggak terciptanya keadilan dan keberpihakan pada kaum yang lemah, kaum yang tertindas. Sejalan dengan pemikiran ini, secara umum, fungsi pendidikan adalah tranformasi kebudayaan dan nilai kepada peserta didik agar mampu memahami, menginternalisasikan dan menyampaikan kepada generasi berikutnya (Mujib 2012).

Wacana yang banyak berkembang di kalangan akademisi bidang akuntansi adalah ranah penelitian pendidikan akuntansi itu lebih diarahkan ke penelitian tindakan kelas (PTK) yang bersifat deskriptif-kualitatif (Bakhtiar 2013; Pradana 2013), eksperimen (Suyono 2013), korelasional (Prabowo 2013; Febriastuti 2013), maupun akuntansi keperilakuan (Fitriana dan Baridwan 2012) yang notabene banyak 
dilakukan di kampus keguruan/IKIP (Institut Keguruan dan Ilmu Pendidikan). Nyatanya, di perguruan tinggi ilmu "murni" pun juga terjadi proses pendidikan bukan? Bahkan sangat banyak sekali nilai-nilai yang melekat dalam ilmu "murni" dan tidak menjadi perhatian para akademisi untuk dijadikan esensi penelitian. Padahal, nilai-nilai tersebut akan melekat dan mengiringi jati diri mahasiswa ketika akan terjun ke dunia kerja.

Bagaikan semilir angin kesejukan yang berhembus lirih, kehadiran beberapa penelitian yang mempunyai "roh" kritis dalam pendidikan akuntansi menjadi suatu arah pemikiran baru yang patut untuk direnungkan dan ditelusuri kebenarannya. Ya, karya - karya ilmiah tersebut secara tidak langsung memberikan "warna" baru dalam pendidikan akuntansi, dimana banyak orang memandang dan memahami bahwa pendidikan akuntansi baik - baik saja tanpa adanya "sesuatu" yang melatarbelakanginya, ternyata terkuak beberapa fakta yang sangat mengejutkan bagi kalangan dunia akademisi maupun profesional. Karya ilmiah pertama yang dapat dijadikan rujukan bagi kaum pendidik kritis adalah penelitian Kamayanti (2011) yang bertujuan untuk membangun kesadaran tentang adanya penjara "keindahan" (maskulinitas, kolonisasi dan relativitas) yang ingin dicapai dalam pendidikan akuntansi, mengkritisi penjara ini serta mengusulkan sudut pandang alternatif tentang bentuk pendidikan akuntansi. Ketiga konsep itulah yang menjadi dasar filosofi pendidikan akuntansi saat ini bersifat sekularisme. Metodologi yang dipakai dalam penelitian ini adalah Extended Dialogic Methodology, sebuah metodologi yang diadaptasi dan diekstensikan dari Paulo Freire untuk mendobrak penjaran "keindahan". Berdasarkan metodologi tersebut, metode penelitian dilakukan dalam dua tahap : refleksi dan aksi. Temuan dalam penelitian ini merupakan suatu rekonstruksi pendidikan akuntansi yang terbebaskan, baik itu dari dari filosofi sampai dengan praktik. Pendidikan akuntasi yang terbebaskan memiliki bentuk Filosofi Kesatuan, Mazhab Humanisme, Konsep Pembelajaran Dialogis Terekstensi, dan Aksi Dialogis Terekstensi. Dari hasil penelitian ini, para pendidik ilmu akuntansi khususnya dapat mengambil hikmah bahwa secara tidak sadar kita sudah terlena dengan penjara "keindahan" ini dan ternyata 
telah direncanakan oleh kaum kapitalis.

Serupa namun tak sama, penelitian Ekasari (2012) yang bertujuan untuk merekonstruksi pendidikan akuntansi di Pendidikan Tinggi Vokasi (PTV) dimana pendidikan secara umum dan pendidikan akuntansi secara khusus serta ilmu akuntansi itu sendiri sarat dengan nilai Kapitalisme, Materialisme, Individualisme dan Sekularisme (KMIS). Rekonstruksi perlu dilakukan untuk menjadikan peserta didik tidak hanya terampil di bidang ilmu akuntansi melainkan pentingnya internalisasi unsur Etika, Moral dan Spiritual (EMS) ketika memasuki dunia kerja. Menarik untuk dicermati dari temuan penelitian ini adalah bahwasanya pendidik di PTV (Perguruan Tinggi Vokasi) sebaiknya memahami filosofi pendidikan dan mengenalkan pengaruh dari ilmu akuntansi terhadap masyarakat dan lingkungan. Peserta didik juga sebaiknya diajari untuk berfikir kritis sehingga tidak hanya menjadi orang yang pragmatis, tetapi juga reflektif, empirik dan futuristik. Dalam materi pendidikan akuntansi di PTV sebaiknya diinternalisasikan nilai - nilai EMS sehingga dapat mereduksi nilai - nilai KMIS. Penelitian ini menggunakan epistimologi 3ling untuk me[re]konstruksi pendidikan akuntansi di PTV. Disisi lain, 3ling juga digunakan sebagai metodologi ketika tiap elemen dari 3ling tersebut bekerja secara sendiri-sendiri. Ngerti digunakan untuk menjustifikasi pemahaman kesadaran informan berdasarkan pengalaman mereka. Ngrasa digunakan untuk mencari the others dari pendidikan akuntansi. Ngelakoni digunakan untuk menginternalisasikan nilai - nilai lain yang dihasilkan dari proses ngrasa.

Nilai-nilai yang melekat dalam pendidikan akuntansi juga pernah diteliti oleh Bakhtiar (2015). Tujuan dari penelitian ini adalah menelaah realitas pendidikan akuntansi di sebuah perguruan tinggi dan merumuskan konsep tujuan pendidikan akuntansi sesuai dengan nilai-nilai pemikiran $\mathrm{Ki}$ Hadjar Dewantara. Secara redaksional, rumusan konsep tujuan pendidikan akuntansi yaitu "Membentuk manusia yang sempurna dengan mensucikan batin dan menertibkan lahirnya melalui nilai spiritualitas, budi pekerti dan kemerdekaan".

Setelah membaca dan menelaah substansi dari penelitian-penelitian di atas, maka perlunya sebuah kontemplasi atas pemaknaan tujuan pendidikan 
akuntansi dari berbagai perspektif sangat diperlukan agar dapat diketahui perbedaan dari masing-masing perspektif tersebut. Mengapa kontemplasi? Karena memang untuk memaknai berbagai perspektif tujuan pendidikan akuntansi memerlukan renungan dan pikiran yang fokus agar tidak melenceng dari substansi yang telah digariskan oleh para peneliti pendidikan akuntansi "murni" tersebut.

\section{METODE PENELITIAN}

Pendekatan yang digunakan dalam penelitian ini adalah pendekatan kualitatif dengan paradigma interpretif sebagai landasan metodologis penelitian. Menurut Creswell (2012:4) yang menyatakan bahwa penelitian kualitatif merupakan metode - metode untuk mengeksplorasi dan memahami makna yang - oleh sejumlah individu atau sekelompok orang - dianggap berasal dari masalah sosial atau kemanusiaan. Salah satu karakteristik penting dalam penelitian kualitatif adalah peneliti berperan sebagai instrumen kunci (researcher as key instrument) karena peneliti mengumpulkan sendiri data melalui dokumentasi, observasi perilaku, atau wawancara dengan para partisipan
(Creswell 2012:261).

Paradigma yang digunakan dalam penelitian ini adalah paradigma interpretif. Triyuwono (2011:4) menjelaskan bahwa dalam paradigma ini tidak menggunakan ilmu pengetahuan untuk menjelaskan dan memprediksi, tetapi untuk memahami (to understand). Paradigma ini saya ${ }^{1}$ rasa tepat jika digunakan dalam penelitian ini karena proses kontemplasi yang telah saya lakukan bertujuan untuk memahami berbagai perspektif dalam merumuskan tujuan pendidikan akuntansi. Dengan kata lain, memahami disini memerlukan proses yang panjang dan tidaklah mudah. Saya harus membaca dan memahami secara mendalam beberapa penelitian pendidikan akuntansi yang tertuang dalam tesis maupun disertasi.

\section{PEMBAHASAN}

\subsection{Interpretasi Tujuan Pendidikan}

\section{Akuntansi dalam Perspektif}

\section{Ekasari (2012)}

Salah satu penelitian yang menjadi rujukan dalam penelitian ini adalah Ekasari (2012), dimana penelitian

\footnotetext{
1 Penggunaan kata "saya" merupakan suatu kesengajaan untuk menekankan penggunaan subyektifitas pada penelitian ini (Kamayanti, 2012).
} 
Ekasari (2012) membahas dan menggunakan metodologi tringa (ngerti, ngrasa, ngelakoni) yang merupakan salah satu pemikiran $\mathrm{Ki}$ Hadjar Dewantara. Argumentasi mengapa saya membahas penelitian Ekasari (2012) karena dalam salah satu bab penelitian doktoralnya ini, beliau merekonstruksi tujuan pendidikan akuntansi yang ada di PTV (Perguruan Tinggi Vokasi). Maka dari itu, saya perlu menjelaskan tujuan pendidikan akuntansi tersebut sebagai bahan referensi penelitian ini. Sebenarnya tidak hanya tujuan pendidikan akuntansi saja yang direkonstruksi dalam penelitian Ekasari (2012) ini, ada beberapa elemen dalam pendidikan akuntansi (khususnya di PTV) yang perlu diperbaiki demi terciptanya keseimbangan nilai dan norma-norma kehidupan, di antaranya dari unsur pendidik, peserta didik, materi pendidikan atau bahan ajar, dan juga unsur pembelajaran.

Proses pendidikan sudah sepatutnya dapat membentuk jati diri dan karakter peserta didik menjadi lebih seimbang, tidak berfokus pada salah satu kecerdasan saja. $Y a$, dalam ranah pendidikan akuntansi, tujuan pendidikan akuntasi merupakan arah ke mana peserta didik akan dibentuk melalui proses pendidikan tersebut. Apakah hanya dibekali dengan kecerdasan kognitif, kecerdasan budi pekerti, kecerdasan spiritual atau kah keseimbangan antara ketiganya? Sebagai bahan referensi, Ekasari (2012:236) mendefinisikan tujuan pendidikan akuntansi di PTV sebagai berikut.

"Untuk mendidik peserta didik menjadi orang yang ahli di bidang akuntansi, yang menjunjung dan mengamalkan nilai-nilai etika moral dan spiritual, menjaga profesionalisme dan bermanfaat bagi dirinya sendiri, masyarakat dan lingkungan".

Dari definisi tujuan pendidikan akuntansi (khususnya di PTV) yang telah dicetuskan oleh Ekasari (2012) dapat diambil beberapa makna substantif yang terkandung di dalamnya, antara lain aspek kognitif, afektif dan psikomotorik. Berikut ini penjelasan lebih detailnya.

Pertama, terkait dengan aspek kognitif, rekonstruksi tujuan pendidikan akuntansi di PTV oleh Ekasari (2012) menghendaki peserta didik untuk memahami materi akuntansi yang telah diberikan selama proses belajar mengajar. Hal ini terlihat dari kutipan kalimat "ahli di bidang akuntansi" yang 
tercantum dalam definisi tujuan pendidikan akuntansi di PTV. Tentu saja sebagai suatu hal yang wajar jika peserta didik harus mempunyai kemampuan (capability) di bidang akuntansi karena ketika terjun ke dunia kerja, keahlian akuntansi ini akan menunjang pekerjaan sebagai akuntan.

Kedua, dalam aspek afektif, definisi tujuan pendidikan akuntansi oleh Ekasari (2012) ini mengharapkan peserta didik untuk mempunyai dan mengamalkan nilai-nilai etika, moral dan spiritual dalam kehidupan seharihari. Hal ini ditegaskan dengan kutipan kalimat "menjunjung dan mengamalkan nilai-nilai etika moral dan spiritual" yang tercantum dalam definisi tujuan pendidikan akuntansi di PTV. Arti penting internalisasi nilai-nilai etika, moral dan spiritual dalam pendidikan akuntansi akan membentuk karakter peserta didik yang lebih seimbang, baik itu kecerdasan kognitif maupun afektifnya. Harapannya ketika sudah terjun ke dunia kerja, peserta didik dapat menjadi manusia yang mengamalkan nilai etika, moral dan spiritual dalam setiap pengambilan keputusan terkait pekerjaannya, tidak ada lagi kecurangan (fraud) maupun manipulasi laporan keuangan demi kepentingan pribadi (self interest).

Ketiga, aspek psikomotorik merupakan salah satu aspek penting dalam dunia pendidikan, tak terkecuali pendidikan akuntansi. Dalam tujuan pendidikan akuntansi di PTV yang dicetuskan oleh Ekasari (2012), saya mendapatkan esensi aspek psikomotorik dalam kutipan kalimat "menjaga profesionalisme dan bermanfaat bagi dirinya sendiri, masyarakat dan lingkungan". Hal ini berarti, peserta didik diharapkan untuk tetap bersikap profesionalisme dalam menjalankan setiap tahapan pekerjaannya, karena sebagai seorang akuntan tentu saja akan banyak "godaan" yang dilayangkan oleh berbagai perusahaan demi kepentingan perusahaan tersebut. Sebagai contoh, manajemen laba (earnings management), manipulasi pajak, kecurangan laporan audit dan masih banyak lagi yang dapat "dimainkan" oleh para akuntan demi kepentingan perusahaan. Sungguh, akuntan itu mempunyai pengaruh yang besar dalam kelangsungan hidup (going concern) bagi perusahaan yang bersangkutan sehingga banyak cara untuk "menggoda" akuntan agar menuruti keinginan pemilik perusahaan. Maka dari itulah, peran nilai-nilai etika, moral 
dan spiritual sebagai "benteng pertahanan" agar tidak terjadi segala bentuk kecurangan (fraud), karena sejatinya akuntansi merupakan bentuk pertanggungjawaban (accountability) akuntan kepada Allah SWT, pemilik perusahaan dan lingkungan sekitar (environmental).

Sejatinya, rekonstruksi pendidikan akuntansi yang dilakukan Ekasari (2012) dalam berbagai unsur pendidikan (tujuan pendidikan, pendidik, peserta didik, materi pendidikan atau bahan ajar dan metode pembelajaran akuntansi) merupakan suatu bentuk usaha untuk mencapai keseimbangan kehidupan bagi peserta didik. Keseimbangan untuk mencapai kecerdasan secara phisik (intelektualitas) dan metaphisik (EMS), keseimbangan filosofi antara pragmatisme dan rasionalisme, dan keseimbangan dalam berpikir kritis dan kreatif (Ekasari, 2012:243-244). Keseimbangan dalam beberapa hal ini tentunya tidak bisa dimaknai sama rata, karena setiap peserta didik mempunyai porsi (maqam) sendiri terkait pemikiran yang dimilikinya. Esensi dalam penelitian Ekasari (2012) ini adalah keseimbangan antara kecerdasan, nilai dan perilaku yang seharusnya dimiliki oleh peserta didik, namun seimbang tidaklah harus sama rata.

\subsection{Interpretasi Tujuan Pendidikan Akuntansi dalam Perspektif Bakhtiar (2015)}

Hasil pemaknaan tujuan pendidikan akuntansi di PTV (Perguruan Tinggi Vokasi) oleh Ekasari (2012) sedikit banyak dapat memberikan gambaran akan tujuan pendidikan akuntansi yang ingin saya formulasikan dalam penelitian ini. Mulai dari substansi yang seharusnya ada dalam definisi tujuan pendidikan akuntansi hingga konsekuensi logis yang akan diterapkan dalam pendidikan akuntansi. Tentunya formulasi tujuan pendidikan akuntansi yang saya bangun ini mempunyai dasar nilai pemikiran KHD yaitu nilai spiritualitas, budi pekerti dan kemerdekaan (Bakhtiar, 2015).

Konsep tujuan pendidikan akuntansi dengan redaksional "Membentuk manusia yang sempurna dengan mensucikan batin dan menertibkan lahirnya melalui nilai spiritualitas, budi pekerti dan kemerdekaan" bisa dikatakan suatu konsep tujuan pendidikan yang masih "umum". Maka dari itu, perlunya penjabaran konkret yang harus saya 
lakukan agar lebih terasa pendidikan "akuntansinya". Di samping itu, saya perlu untuk menyesuaikan dengan tujuan pendidikan nasional sebagai pedoman dalam perumusan tujuan pendidikan akuntansi. Bagaimanapun juga, tujuan pendidikan nasional merupakan tolok ukur pendidikan dalam konteks umum (meliputi berbagai cabang keilmuan) di Indonesia.

Sebelum merumuskan definisi tujuan pendidikan akuntansi, terlebih dahulu saya harus memikirkan konsep kompetensi yang harus dimiliki oleh peserta didik dan tentu saja hal ini menjadi substansi tujuan pendidikan akuntansi itu sendiri. Berkaitan dengan hal ini, saya merujuk pemikiran Kamayanti (2011:182) yang merumuskan konsep pembelajaran EDAE (Extended Dialogic Accounting Education) yang tercantum dalam tabel berikut:
Tabel 1 Konsep Pembelajaran EDAE

\begin{tabular}{|c|c|}
\hline $\begin{array}{l}\text { Kompetensi } \\
\text { Rasional }\end{array}$ & $\begin{array}{ll}\text { - } & \text { Peningkatan } \\
& \text { pengetahuan } \\
\text { - } & \text { Proses mengingat } \\
\text { - } & \text { Memperoleh fakta- } \\
& \text { fakta (empiris) } \\
\text { - } & \text { Menjabarkan } \\
& \text { pengertian (arti) } \\
\text { - } & \text { Proses memahami }\end{array}$ \\
\hline $\begin{array}{l}\text { Kompetensi } \\
\text { Kritis }\end{array}$ & 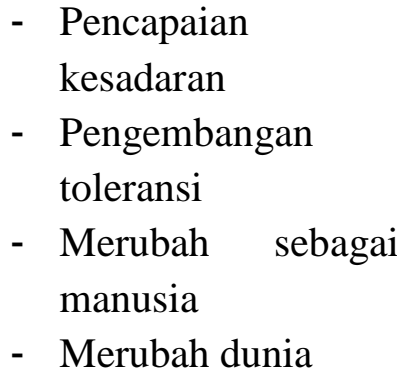 \\
\hline $\begin{array}{l}\text { Kompetensi } \\
\text { Intuisi }\end{array}$ & $\begin{array}{llr}\text { - } & \text { Memahami } & \text { diri } \\
\text { dengan } & \text { proses } \\
\text { intuisi } & \\
\text { - } & \text { Memajukan } & \\
& \text { perasaan } & \text { budi } \\
& \text { pekerti } & \end{array}$ \\
\hline $\begin{array}{l}\text { Kompetensi } \\
\text { Spiritual }\end{array}$ & $\begin{array}{ll}\text { - } & \text { Aktivitas kepatuhan } \\
\text { ke arah spiritual } \\
\text { - } & \text { Memajukan } \\
\text { kesadaran } \\
\text { Ketuhanan }\end{array}$ \\
\hline
\end{tabular}


Merujuk pada ke empat kompetensi yang harus dimiliki oleh peserta didik di atas (kompetensi rasional, kritis, intuisi dan spiritual), ketika saya merumuskan definisi tujuan pendidikan akuntansi juga harus mencakup ke empat kompetensi ini. Hal ini karena dalam pemikiran saya, ke empat kompetensi sudah mencakup dimensi kecerdasan yang memang harus dimiliki oleh peserta didik sebagai landasan berfikir, nilai dan pembentukan karakter ketika nantinya terjun ke dunia kerja yang penuh dengan dinamika sosial.

Konsekuensi logis merupakan suatu penjabaran dari sesuatu yang bersifat umum (abstrak) agar lebih spesifik dan konkret. Dalam konteks penelitian ini, konsep tujuan pendidikan akuntansi memang masih terkesan umum. Hal ini menjadi suatu kelumrahan karena memang KHD adalah seorang putra bangsa yang fokus berjuang di ranah pendidikan umum. Maka dari itu, tugas saya sebagai peneliti di bidang pendidikan akuntansi adalah bagaimana konsep tujuan pendidikan akuntansi yang telah saya rumuskan sebelumnya sehingga lebih konkret dan spesifik menjadi sebuah definisi tujuan pendidikan akuntansi yang mencakup kompetensi rasional, kritis, intuisi dan spiritual.

Konsep merupakan suatu uraian abstrak (umum) yang digunakan sebagai landasan atau rancangan suatu pemikiran ataupun perbuatan. Ketika konsep tujuan pendidikan akuntansi dengan redaksional "Membentuk manusia yang sempurna dengan mensucikan batin dan menertibkan lahirnya melalui nilai spiritualitas, budi pekerti dan kemerdekaan", maka secara logika, definisi tujuan pendidikan akuntansi harus diturunkan dari redaksional konsep tujuan pendidikan akuntansi tersebut. Oleh karena itu, tujuan pendidikan akuntansi dalam konteks penelitian ini yaitu "Mengajarkan peserta didik agar mempunyai kompetensi akuntansi yang mengedepankan nilai spiritual, budi pekerti dan kemerdekaan demi terciptanya manusia yang sempurna lahir dan batin". Untuk lebih memperjelas tujuan pendidikan akuntansi ini, saya akan menjabarkan ke dalam beberapa uraian berikut ini.

Pertama, kompetensi rasional (akuntansi) tidak bisa dipungkiri adalah salah satu faktor penting ketika terjun ke dunia kerja. Tentu saja sebagai peserta didik di bidang akuntansi haruslah mempunyai kecakapan dalam 
membuat laporan keuangan, menghitung pajak, menetapkan persediaan bahan baku produksi dan lain sebagainya. Namun, keahlian pencatatan akuntansi haruslah ditunjang dengan kompetensi lain agar terjadi keseimbangan yang harmonis. Terkait dengan kompetensi rasional ini, ternyata KHD juga memberikan perhatian terhadap pentingnya aspek rasional (kognitif) dalam dunia pendidikan, tentunya harus diimbangi dengan halusnya budi pekerti dan kesehatan raga (fisik). Hal ini dapat dilihat dalam kutipan di bawah ini.

"Usaha pendidikan ditujukan kepada : a. Halusnya budi; b. Cerdasnya otak; c. Sehatnya badan. Ketiga usaha itu akan menjadikan lengkap dan larasnya hidup manusia di dunia" (Ki Hadjar Dewantara, 1977:303).

Kedua, kompetensi kritis dalam diri peserta didik merupakan suatu hal yang penting untuk diimplementasikan. Dalam tujuan pendidikan akuntansi ini, makna kompetensi kritis tercermin dalam nilai kemerdekaan, di mana peserta didik selalu diberikan kesadaran untuk menjadi manusia yang bebas, mandiri dan tetap berpihak pada kepentingan bangsa dan negara ketika hendak mengambil setiap keputusan. Sebagai contoh, ketika peserta didik sudah ahli di bidang akuntansi (mainstream), maka sudah selayaknya pendidik juga membangkitkan kesadaran kritis kepada peserta didik agar mempunyai perspektif lain terhadap ilmu akuntansi itu sendiri, sehingga kecerdasan peserta didik menjadi semakin kompleks. Dalam pemikirannya, KHD juga berbicara tentang arti penting bersikap kritis (bebas, mandiri dan cinta pada bangsa dan negara) dalam dunia pendidikan seperti yang tertuang dalam petikan berikut ini.

"Bahwa dalam sifat bentuk pendidikan dan pengajaran kita, saya menganjurkan pula harus adanya corak-warna kebangsaan dalam sistem pendidikan dan pengajaran rakyat kita" (Ki Hadjar Dewantara, 1977:172).

"Kemerdekaan adalah sifat hidup manusia yang berbudaya. Kemerdekaan mempunyai dua sifat, yaitu lahirnya sifat "bebas", yakni lepas dari paksaan atau perintah orang lain. Sifat yang kedua yaitu sifat batinnya, boleh kita anggap isinya kebebasan tadi, dan sifat ini tidak lain ialah sifat "mandiri", yakni berdiri sendiri. Demikianlah arti perkataan "merdeka" yang sejati: dapat berdiri sendiri dan bebas dari perintah paksaan pihak lain" (Ki Hadjar Dewantara, 1977:478-479). 
Ketiga, kompetensi intuisi dalam tujuan pendidikan akuntansi ini tercermin dalam nilai budi pekerti di mana peserta didik dididik agar mempunyai keseimbangan cipta, rasa dan karsa (Tri-sakti) jiwa ketika menjalani setiap proses belajar mengajar akuntansi. Berkaca pada penjelasan lebih rinci di bab dua tentang makna nilai budi pekerti ini, sebenarnya esensi dari nilai budi pekerti ini sudah mencakup kecerdasan rasional (kognitif/akal) sebagai refleksi dari proses "cipta", kecerdasan intuisi (afektif) sebagai refleksi dari proses "rasa", dan kecerdasan psikomotorik (perilaku) sebagai refleksi dari proses "karsa". Dengan demikian, ketika peserta didik sudah dibekali dengan kompetensi intuisi yang meliputi nilai budi pekerti, maka dengan sendirinya keseimbangan Tri-sakti jiwa peserta didik akan menghasilkan tiga kecerdasan tersebut secara bersamaan. Justifikasi akan pemahaman tersebut dapat dilihat dari kutipan dibawah ini.

"Pendidikan dan pengajaran yang terluhur adalah terkandung dalam Khodrat-alam. Untuk mengetahui Khodrat-alam itu perlulah orang mempunyai wijsheid, atau bersihnya budi, yang harus terdapat dari tajamnya angan-angan, halusnya rasa, dan suci kuatnya kemauan, yaitu sempurnanya ciptarasa-karsa. Maksud pendidikan itu ialah sempurnanya hidup manusia, hingga dapat memenuhi segala keperluan hidup lahir dan batin yang kita dapat dari khodrat-alam" (Ki Hadjar Dewantara, 1977:9394).

Keempat, kompetensi spiritual merupakan kompetensi yang wajib diinternalisasikan kepada peserta didik karena dengan spiritualitas lah peserta didik mempunyai kesadaran bahwa semua yang dilakukannya di dunia (terutama berkaitan dengan keputusanakuntansi) akan dipertanggungjawabkan kepada Tuhan YME. Hal ini merupakan langkah konkret bahwa Tuhan YME selalu hadir dalam setiap denyut nadi kita dan sudah sepatutnya kita selalu ingat akan keberadaanNya. Inilah esensi dari Tauhid dalam Islam. Dengan demikian, segala bentuk dan faktorfaktor pendukung adanya kecurangan (fraud) dalam profesi akuntan dapat diminimalisir sekecil mungkin agar tidak terjadi. Oleh karenanya, KHD secara umum memberikan gambaran penyelarasan pendidikan dengan nilainilai spiritualitas menjadi hal yang harus dilakukan demi terciptanya ketertiban lahir dan batin peserta didik. Semua hal ini tertuang dalam kutipan berikut ini: 
"Dalam garis-garis adab perikemanusiaan, seperti terkandung dalam segala pengajaran agama dan kesusilaan, maka pendidikan dan pengajaran nasional bersendi pada agama dan atau kebudayaan bangsa serta menuju ke arah "keselamatan" dan "kebahagiaan" masyarakat" (Ki Hadjar Dewantara, 1977:232).

"Pendidikan itu segala pemeliharaan lahir dan batin terhadap pada anak-anak untuk dapat memajukan hidupnya lahir atau jasmani dan batin atau rokhani" (Ki Hadjar Dewantara, 1977:436).

Sebagai catatan, saya sengaja menggunakan kata kompetensi spiritual dan tidak merujuk pada suatu agama apapun (walaupun sebagai rujukan utama adalah pemikiran KHD yang jelas beragama Islam) karena pada dasarnya Indonesia merupakan negara pluralisme yang menjunjung tinggi toleransi antar umat beragama. Begitu pula dengan tujuan pendidikan akuntansi yang telah saya rumuskan ini adalah untuk seluruh umat beragama di Indonesia tanpa membedakan SARA (Suku, Agama dan Ras). Hal ini sesuai dengan diturunkannya Islam sebagai agama yang Rahmatan lil'alamin ${ }^{2}$.

Terkait dengan redaksional "manusia yang sempurna lahir dan

\footnotetext{
${ }^{2}$ Rahmat untuk semesta alam.
}

batinnya" dalam tujuan pendidikan yang telah saya rumuskan di atas dapat dimaknai sebagai perwujudan cita-cita luhur KHD dalam membentuk generasi bangsa Indonesia di masa yang akan datang. Bagaimana langkah konkretnya dalam pendidikan akuntansi? Sejatinya, filosofi manusia sempurna lahir dan batinnya merupakan esensi dari candrasengkala "Suci Tata Ngesti Tunggal". Untuk lebih jelasnya terdapat dalam kutipan berikut ini.

"Untuk mengingat tahun berdirinya Taman Siswa, maka ditandai dengan pemakaian candrasengkala yang berbunyi "Suci Tata Ngesti Tunggal" artinya suci batinnya, tertib lahirnya, luhur maksudnya dan sempurna tujuannya. Suci tertib bercita-cita tunggal, arti "tunggal" di sini ialah bersatu dalam arti luas. Boleh diartikan bersatu dengan Tuhan atau ditafsirkan sebagai "sempurna" (Soeratman, 1989:112113).

Sungguh, bagi saya pribadi, memahami filosofi yang sangat dalam maknanya membutuhkan pengetahuan yang luas yaitu dengan membaca banyak referensi agar mendapatkan pemaknaan yang utuh dan komprehensif. Dalam kutipan di atas,

3 Menurut KBBI, candrasengkala berarti rumusan tahun dengan kata-kata, yang setiap kata melambangkan angka, dibaca dari depan dan ditafsirkan dari belakang; kronogram Jawa yang memakai sistem perhitungan bulan. 
saya dapat memaknai bahwa manusia yang suci batinnya, tertib lahirnya merupakan cerminan manusia yang sangat dekat dan cinta kepada Tuhannya. Tentunya pendidikan akuntansi sangat diharapkan untuk membentuk peradaban manusia yang "sempurna" ini, yaitu dengan menghubungkan setiap elemen dalam pendidikan akuntansi dengan Tuhan YME. Tidak ada sedikitpun hal yang terlepas dari kuasaNya, semua yang ada di dunia ini bertasbih menyebut asmaNya. Allahu'akbar..

Ketika berbicara konteks tujuan pendidikan dalam Islam, seperti yang dikemukakan oleh Al-Attas (1993:150151) juga menyatakan hal yang serupa dengan pemikiran KHD, yaitu :

"The aim of education in Islam is therefor to produce a good man. It means, the fundamental element inherent in the Islamic concepts of education is the inculcation of $a d a b$, for it is adab in the all inclusive sense here mean as encompassing the spiritual and material life of man that instills the quality if goodness that is sought after".

$Y a$, tujuan pendidikan dalam Islam adalah membentuk manusia yang baik dengan menanamkan elemen fundamental dalam konsep pendidikan Islam yaitu $a d a b$ (mencakup kehidupan spiritual dan material). Apa yang menjadi esensi pemikiran Al-Attas (1993) terkait tujuan pendidikan Islam yang menyeimbangkan kehidupan spiritual (batin) dengan kehidupan material (lahir) sesuai dengan pemikiran KHD yang juga menginginkan agar pendidikan dapat membentuk manusia sempurna, lahir dan batinnya.

Sebagai justifikasi atas esensi tujuan pendidikan akuntansi yang telah saya uraikan sebelumnya ternyata sesuai dengan tujuan pendidikan nasional yang tercantum dalam Undang-Undang Republik Indonesia No. 20 tahun 2003 tentang sistem pendidikan nasional bab II pasal 3 berikut.

"Pendidikan nasional bertujuan untuk berkembangnya potensi peserta didik agar menjadi manusia yang beriman dan bertakwa kepada Tuhan Yang Maha Esa, berakhlak mulia, sehat, berilmu, cakap, kreatif, mandiri, dan menjadi warga negara yang demokratis serta bertanggung jawab".

Saya memaknai bahwa hakikat tujuan pendidikan nasional juga memperhatikan ke empat kompetensi (rasional, kritis, intuisi dan spiritual) yang tercermin dengan redaksional "menjadi manusia yang beriman dan bertakwa kepada Tuhan Yang Maha Esa" merupakan refleksi kompetensi 
spiritual, redaksional "berakhlak mulia" merupakan refleksi kompetensi intuisi, redaksional "berilmu, cakap" merupakan refleksi kompetensi rasional dan redaksional "kreatif, mandiri dan menjadi warga negara yang demokratis serta bertanggung jawab" merupakan refleksi kompetensi kritis nasionalis. Substansi tujuan pendidikan nasional ini juga sesuai dengan UUD 1945 Bab XIII tentang Pendidikan dan Kebudayaan pasal 31 ayat 3 berikut.

"Pemerintah mengusahakan dan menyelenggarakan satu sistem pendidikan nasional, yang meningkatkan keimanan dan ketakwaan serta akhlak yang mulia dalam rangka mencerdaskan kehidupan bangsa, yang diatur dengan undang-undang".

Untuk menambah referensi atas justifikasi esensi tujuan pendidikan akuntansi yang telah saya rumuskan di atas, disini saya mencoba untuk mempelajari capaian pembelajaran $(\mathrm{CP})$ yang terkandung dalam KKNI (Kerangka Kompetensi Nasional Indonesia). Penjelasan lebih lanjut akan capaian pembelajaran ini terurai dalam kutipan berikut ini.
"Capaian pembelajaran dapat dipandang sebagai resultan dari hasil keseluruhan proses belajar yang telah ditempuh oleh seorang pembelajar/mahasiswa selama menempuh studinya pada satu program studi tertentu, di mana unsur capaian pembelajaran mencakup: Sikap dan tata nilai, Kemampuan, Pengetahuan, dan Tanggung jawab/hak" (Tim Kurikulum dan Pembelajaran Direktorat Pembelajaran dan Kemahasiswaan, 2014:14).

Capaian pembelajaran dalam hemat saya hampir sama maknanya dengan tujuan pembelajaran, namun disini perbedaannya adalah cakupan pembelajaran digunakan sebagai dasar kompetensi untuk pembuatan kurikulum pendidikan tinggi, sedangkan tujuan pembelajaran dibuat oleh pendidik yang biasanya tercantum dalam RPS (Rencana Pembelajaran Semester).

Cakupan yang disyaratkan sebagai dasar capaian pembelajaran yang pertama adalah sikap dan tata nilai. Penjelasan lebih detail terkait sikap dan tata nilai ini tercantum dalam deskripsi umum KKNI dalam lampiran Perpres No. 8 tahun 2012 sebagai berikut. 
“(a) Bertaqwa kepada Tuhan Yang Maha Esa. (b) Memiliki moral, etika dan kepribadian yang baik di dalam menyelesaikan tugasnya. (c) Berperan sebagai warga negara yang bangga dan cinta tanah air serta mendukung perdamaian dunia. (d) Mampu bekerja sama dan memiliki kepekaan sosial dan kepedulian yang tinggi terhadap masyarakat dan lingkungannya. (e) Menghargai keanekaragaman budaya, pandangan, kepercayaan, dan agama serta pendapat/temuan original orang lain. (f) Menjunjung tinggi penegakan hukum serta memiliki semangat untuk mendahulukan kepentingan bangsa serta masyarakat luas".

Yang perlu digarisbawahi adalah poin (a), (b) dan (c) di mana jika dikaitkan dengan substansi tujuan pendidikan akuntansi dapat mencakup nilai spiritual, budi pekerti dan kemerdekaan yang menjadi landasan pendefinisian tujuan pendidikan akuntansi tersebut.

Cakupan kedua yaitu kemampuan, yang mana sangat berkaitan dengan kompetensi rasional (kognitif) di mana peserta didik dalam pendidikan akuntansi diharapkan mempunyai kapabilitas di bidang akuntansi. Cakupan ketiga, yaitu pengetahuan, di mana selain mempunyai keahlian di bidang akuntansi, peserta didik hendaknya mempunyai ilmu pengetahuan dan teknologi (IPTEK) guna menunjang pekerjaannya sebagai seorang akuntan profesional, dan terakhir, cakupan ke empat, yaitu tanggung jawab/hak yang berarti peserta didik mempunyai tanggung jawab terhadap pekerjaan dengan sebaikbaiknya sebelum menuntut haknya kepada pihak tempat dia bekerja.

Untuk lebih mempermudah dalam melihat perbedaan tujuan pendidikan akuntansi dalam perspektif Ekasari (2012) dan Bakhtiar (2015), berikut ini saya sajikan matriks yang menjelaskan definisi tujuan pendidikan akuntansi beserta kompetensi-kompetensi yang menjadi substansi dari tujuan pendidikan akuntansi tersebut. 
Tabel 2 Matriks Tujuan Pendidikan Akuntansi

\begin{tabular}{|c|l|l|}
\hline Perspektif & \multicolumn{1}{|c|}{ Tujuan Pendidikan Akuntansi } & \multicolumn{1}{|c|}{ Kompetensi } \\
\hline Ekasari & Untuk mendidik peserta didik & Kognitif, afektif (spiritual) \\
(2012) & menjadi orang yang ahli di bidang & dan psikomotorik \\
& akuntansi, yang menjunjung dan & \\
mengamalkan nilai-nilai etika moral & \\
& dan spiritual, menjaga & \\
& profesionalisme dan bermanfaat bagi & \\
& dirinya sendiri, masyarakat dan & \\
\hline Bakhtiar & lingkungan & \\
Mengajarkan peserta didik agar & Rasional, kritis, intuisi dan \\
& mempunyai kompetensi akuntansi & spiritual \\
& yang mengedepankan nilai spiritual, & \\
& budi pekerti dan kemerdekaan demi & \\
& terciptanya manusia yang sempurna & \\
& lahir dan batin \\
\hline
\end{tabular}

Alhamdulillah, tujuan pendidikan akuntansi yang telah saya rumuskan ternyata linear (sejalan) dengan tujuan pendidikan nasional, UUD 1945 dan juga capaian pembelajaran KKNI (Kerangka Kompetensi Nasional Indonesia). Memang secara redaksional sangatlah berbeda jauh karena tujuan pendidikan akuntansi lebih spesifik mengarah pada cabang ilmu akuntansi sedangkan tujuan pendidikan nasional, UUD 1945 dan capaian pembelajaran KKNI diarahkan untuk pendidikan secara umum, namun secara substansi sangatlah sesuai dan berkesinambungan satu sama lainnya. Ketika saya melihat lebih dalam lagi, ternyata substansi dari tujuan pendidikan akuntansi, tujuan pendidikan nasional, dan capaian pembelajaran KKNI menuju ke arah dan tujuan yang sama, yaitu proses pendidikan dapat membentuk peradaban manusia Indonesia yang sempurna dengan meningkatkan keimanan dan ketakwaan kepada Tuhan YME dan mempunyai akhlak yang mulia.

Amin..amin..amin ya robbal'alamin..

\section{KESIMPULAN}

Pada dasarnya penelitian ini saya tulis untuk memudahkan para penggiat pendidikan akuntansi "murni” agar bisa membedakan substansi penelitian doktoral Ekasari (2012) dan penelitian magister Bakhtiar (2015). Tentunya penelitian pendidikan akuntansi lainnya, Kamayanti (2011), saya jadikan sebagai acuan dan referensi dalam 
formulasi redaksional tujuan pendidikan akuntansi yang menjadi konsekuensi logis konsep tujuan pendidikan akuntansi dalam penelitian magister Bakhtiar (2015).

Penelitian doktoral Ekasari (2012) yang bertujuan merekonstruksi elemenelemen/unsur-unsur dalam pendidikan akuntansi khususnya di PTV (Perguruan Tinggi Vokasi) yaitu tujuan pendidikan, pendidik, peserta didik, materi pendidikan atau bahan ajar dan unsur pembelajaran. Dalam hal ini, saya berfokus untuk memaknai tujuan pendidikan akuntansi di PTV karena sesuai dengan fokus penelitian ini. Secara umum, dalam definisi tujuan pendidikan akuntansi oleh Ekasari (2012) sudah tercakup dimensi kognitif, afektif dan psikomotorik, di mana kecerdasan peserta didik menjadi semakin kompleks jika ketiga dimensi ini dapat diinternalisasikan dengan baik

\section{DAFTAR PUSTAKA}

Al-Attas, Syed Muhammad Naquib. 1993. Islam and Sekularism. Art Printing Works Sdn. Bhd. Kuala Lumpur, Malaysia.

Antonio, M. Syafii. 2009. Muhammad SAW, The Super Leader Super Manager. Jakarta: ProLM Centre \& Tazkia Publishing. melalui pendidikan akuntansi di PTV.

Penelitian magister Bakhtiar (2015) yang merumuskan konsep tujuan pendidikan akuntansi sebagai landasan yang masih bersifat umum memang sudah selayaknya diturunkan menjadi suatu definisi konkret tujuan pendidikan akuntansi sebagai wujud konsekuensi logis atas adanya konsep tersebut. Secara substansi, saya merujuk pada ke empat kompetensi yang dicetuskan Kamayanti (2011) yaitu kompetensi rasional, kritis, intuisi dan spiritual. Berbekal ke empat kompetensi ini, saya dapat merumuskan tujuan pendidikan akuntansi sebagai berikut. "Mengajarkan peserta didik agar mempunyai kompetensi akuntansi yang mengedepankan nilai spiritualitas, budi pekerti dan kemerdekaan demi terciptanya manusia yang sempurna lahir dan batin".

Bakhtiar, Yohan. 2013. Implementasi Pembelajaran Kooperatif Metode Team Accelerated Instruction (TAI) pada Mata Pelajaran Akuntansi untuk Meningkatkan Motivasi dan Hasil Belajar. Jurnal Pendidikan Akuntansi. Vol. 1, No. 3, hlm. 203-211. 
Bakhtiar, Yohan. 2015. Rekonstruksi Konsep Tujuan Pendidikan Akuntansi Melalui Nilai-Nilai Pemikiran Ki Hadjar Dewantara (Studi Kasus Fakultas Ekonomi Universitas Pembelajaran Sejati). Tesis. Program Magister Akuntansi, Program Pascasarjana Fakultas Ekonomi dan Bisnis, Universitas Brawijaya.

Creswell, J. W. 2012. Research Design: Qualitative, Quantitative, and Mix Methods Approaches Third Edition. Achmad Fawaid (penerjemah). Reseach Design: Pendekatan Kualitatif, Kuantitatif dan Mixed. Pustaka Pelajar: Yogyakarta.

Dewantara, Ki Hajar. 1977. Bagian I : Pendidikan. Cetakan kedua. Diterbitkan oleh Madjelis-Luhur Persatuan Taman Siswa. Jogjakarta.

Ekasari, K. 2012. [Re]Konstruksi Pendidikan Akuntansi di Tingkat Pendidikan Vokasi, Melalui Epistimologi 3ling. Disertasi. Program Doktor Ilmu Akuntansi, Program Pascasarjana Fakultas Ekonomi dan Bisnis, Universitas Brawijaya.

Febriastuti, Dina. 2013. Pengaruh Kecerdasan Emosional terhadap Tingkat Pemahaman Akuntansi dengan Kepercayaan Diri sebagai Variabel Pemoderasi pada Siswa Kelas XII Jurusan Akuntansi SMKN Sumenep. Jurnal Pendidikan Akuntansi. Vol. 1, No. 3, hlm. 146-153.
Fitriana, A. dan Baridwan, Z. 2012. Perilaku Kecurangan Akademik Mahasiswa Akuntansi: Dimensi Fraud Triangle. Jurnal Akuntansi Multiparadigma. Vol. 3, No. 2, hlm. 244-256.

Kamayanti, Ari. 2011. Liberating Accounting Education through Beauty and Beyond. Disertasi. Program Doktor Ilmu Akuntansi, Program Pascasarjana Fakultas Ekonomi dan Bisnis, Universitas Brawijaya.

Kamayanti, Ari. 2012. Cinta: Tindakan Berkesadaran Akuntan (Pendekatan Dialogis dalam Pendidikan Akuntansi). Simposium Nasional Akuntansi (SNA) XV Banjarmasin, 20-23 September.

Ki Soeratman. 1989. Kepemimpinan Ki Hajar Dewantara dan Penerapan Sistem Among. (Yogyakarta : MLPTS 1990).

Mujib, Abdul. 2012. Konsep Pendidikan Karakter Berbasis Psikologi Islam. Prosiding Seminar Nasional Psikologi Islam. Hlm. 110.

Peraturan Presiden Republik Indonesia No. 8 tahun 2012 tentang Kerangka Kualifikasi Nasional Indonesia. Sekretariat Negara. Jakarta.

Prabowo, Andri Eko. 2013. Pengaruh Persepsi dan Sikap Guru Akuntansi terhadap Kesiapan Guru dalam Mengimplementasikan KTSP di Sekolah. Jurnal Pendidikan Akuntansi. Vol. 1, No. 3, hlm. 138145. 
Pradana, Indra Ari. 2013. Implementasi Model Pembelajaran Kooperatif Teams-Assisted-Individualization. Jurnal Pendidikan Akuntansi. Vol. 1, No. 3, hlm. 161-169.

Sekretariat Jenderal MPR RI. 2011. Undang-Undang Dasar Negara Republik Indonesia Tahun 1945.

Suyono, Akhmad. 2013. Perbedaan Hasil Belajar dengan Pendekatan Cooperative Learning Tipe Jigsaw dan Tipe STAD pada Mata Pelajaran Ekonomi. Jurnal Pendidikan Akuntansi. Vol. 1, No. 3, hlm. 131-137.

Tim Kurikulum dan Pembelajaran Direktorat Pembelajaran dan Kemahasiswaan. 2014. Buku Kurikulum Pendidikan Tinggi. Direktorat Jenderal Pendidikan
Tinggi, Kementerian Pendidikan dan Kebudayaan. Jakarta.

Triyuwono, Iwan. 2006. Perspektif, Metodologi, dan Teori Akuntansi Syari'ah. Penerbit PT Raja Grafindo Persada.

Triyuwono, Iwan. 2011. "Sususaya" Melampaui Paradigma-Paradigma Metodologi Penelitian. Artikel disampaikan dalam acara Accounting Research Training Series 2, Jurusan Akuntansi Fakultas Ekonomi dan Bisnis, Universitas Brawijaya. 7-8 Desember.

Undang-Undang Republik Indonesia No. 20 tahun 2003 tentang Sistem Pendidikan Nasional. Sekretariat Negara. Jakarta. 